\title{
Eponyymiset idiomit suomen kielessä
}

\author{
Esimerkkitapauksena presidenttiviitteiset verbilausekekonstruktiot
}

\section{Taustaa}

Tässä artikkelissa tarkastellaan erisnimen sisältävää eli eponyymistä verbilausekekonstruktiota (tehdä $+\mathrm{N}_{\text {prop }}-\mathrm{PL}$ ) ja havainnollistetaan näin yhden idiomaattisen konstruktion analyysin avulla, kuinka monipuolista merkitysvaihtelua idiomaattisiin ilmauksiin voi sisältyä. ${ }^{1}$ Käytännössä konstruktio toteutuu esimerkiksi ilmauksessa tehdä Kekkoset, jonka tilanteinen erityismerkitys voi eri konteksteissa vaihdella kaljupäisyydestä palmuun kiipeämiseen tai hallituksen kaatamisesta politiikan tekemiseen saunassa. Merkitysvaihtelu voi olla jopa tyypillistä tällaisille idiomaattisille konstruktioille, jotka sallivat sanastollista vaihtelua.

Suomen kielessä, kuten myös muun muassa englannissa ja ruotsissa, saatetaan erisnimiä käyttää varsinaisen käyttötarkoituksen lisäksi myös yleisnimen tapaan. Jotta appellatiivisesti käytettävä sana erottuisi varsinaisesta erisnimikäytöstä, se on tavallisesti kirjoitettu pienellä alkukirjaimella ja sitä käytetään usein monikossa. Tällöin monikkoa käytetään paljouden ilmaisemisen sijaan abstraktimmin, esimerkiksi yleistämiseen, kuten esimerkeissä 1-3 (ks. myös Penttilä 1957, § 300; Niemi-Nenonen-Penttilä 1998; Nenonen 2002, 2007a; Nenonen-Penttilä 2014a).

(1) Tämä eroaa aiemmasta tuotannostani siten, että koetin tehdä tästä mahdollisimman todenmukaisen - toisin sanoen tästä puuttuvat Coca Colat, urhokekkoset, naamakirjat yms. (http://www.finfanfun.fi/index. php?topic $=32060.0,17.4 .2015$.)

(2) Saunan merkitys päätösten syntypaikkana on Donnerin mukaan vähentynyt siksikin, ettei Suomessa enää ole Kekkosia. (Kielipankki)

1 Kiitämme kahta nimetöntä arvioijaa hyvistä ja rakentavista kommenteista - myös tekstin edelliseen versioon. Mahdollisesti tekstiin jääneet puutteet ja virheet ovat luonnollisesti omiamme. 
(3) 70-luvulla Haloset yms- demarit kiljuivat, että "kaikki yhteistyö lännen kanssa lopetettava". (http://www.iltalehti.fi/keskustelu/showthread. php?t=1201163, 29.4.2015.)

Tarkastelemamme konstruktio näyttää nykymuodossaan olevan melko uusi suomen kielessä. Ilmaustyyppi ja sen merkitys tunnistetaan Isossa suomen kieliopissa, jossa todetaan, että monikkomuotoista erisnimeä voidaan käyttää yleisnimimäisesti ilmauksessa tehdä $x: t$ 'toimia niin kuin kyseisen niminen yksilö on toiminut', esim. aika moni oli tehdä häkkiset eli hyytyä lähtöruutuun (ISK 2004, \$ 597). Göran Karlsson (2000) on tarkastellut sanomalehtiteksteissä esiintyvää monikon käyttötapaa, jossa jo olemassa oleville sanoille annetaan uusia merkityksiä, kun tehdä-verbin objektina oleva henkilönnimi kirjoitetaan appellatiivin tapaan pienellä alkukirjaimella. Lisäksi nimi on monikossa, millä Karlssonin mukaan ilmaistaan henkilön tekoa tai hänen tekemäänsä toimenpidettä, esimerkiksi tehdä kekkoset. Monikollisuus rajoittuu rakenteessa lähinnä muotoon eikä siis ilmaise useutta (mts. 96). Ensimmäiset esimerkit Karlssonin tutkimukseen on poimittu 1980-luvulta, useimmat 1990-luvun lehdistä (mts. 104).

Eponyymiselle verbilausekekonstruktiolle on luonteenmaista, että se on harvinainen sanakirjoissa. Sen esiintymät, kuten idiomit yleensäkin, ovat harvinaisia myös tekstikorpuksissa, koska sen merkitys on tilannesidonnainen ja voi näin ollen vaihdella runsaasti. Toki tilannesidonnainen erityismerkitys kytkeytyy aina jollain tavoin erisnimeen liittyviin mielikuviin, jotka rajoittavat mahdollisia vaihtoehtoja. Itse muoto, konstruktio, on kuitenkin yleinen ja konventionaalinen: Vuonna 2019 julkaistu Suomi24 2017 H2 -korpus (2001-2017) sisältää yli 4 miljardia sanetta. Haku, joka sisältää kaikki tehdä-verbin esiintymät, joiden jäljessä on monikon nominatiivissa tai partitiivissa oleva erisnimi, antoi tulokseksi yhteensä 1366 eponyymikonstruktiota, joista erilaisia on $575 .^{2}$ Eniten konstruktiota esiintyy seuraavilla keskustelualueilla: yhteiskunta (723), paikkakunnat (175) sekä viihde ja kulttuuri (142). Yleisimmät erisnimet ovat Lipponen (39), Trump (36) ja Soini (34). Vaikka yli tuhat erisnimistä viittaa julkisuuden henkilöihin, kuten poliitikkoihin, viihdetähtiin ja historian henkilöihin, on konstruktiossa käytetty myös mm. paikannimiä, yhtiöiden nimiä ja tuotemerkkejä. Muista erottuva alaryhmä ovat keskustelijoiden nimimerkit (15), joiden tulkitsemisessa yleistiedosta ei ole hyötyä, sillä ne liittyvät kulloiseenkin keskusteluketjuun.

Ilmaisutapa näyttäisi olevan käännöslaina englannista, vrt. engl. do a/an $N_{\text {prop }}$, esim. do a Chomsky (4-5) (Penttilä 2006; Clark-Gerrig 1983; englannin ja suomen idiomien vertailusta Nenonen-Penttilä-Niemi 2013). Ruotsin kielessä vastaava konstruktio on göra en/ett $N_{\text {prop }}(6-7)$

(4) It takes an age to do a Chomsky 'luoda mittava tieteellinen ura'. (Penttilä 2006)

2 Kaikki korpuksen eponyymikonstruktiot eivät ole haussa mukana, koska Korpissa käytettävä jäsennin tunnistaa vain isolla alkukirjaimella kirjoitetut erisnimet ja koska haussa olivat mukana vain heti verbin jälkeen tulevat erisnimet. 
(5) Couldn't you help me by doing a Chomsky? 'avata kohteliaasti auton ovi' (Clark-Gerrig 1983, 599)

(6) Centerns Paavo Väyrynen vill göra en Kekkonen och låta bli att stadfästa lagar som inte faller honom i smaken. (http://hbl.fi/opinion/ ledare/2011-11-14/starkt-mandat-utan-f)

(7) Han [Erdogan] vill helt enkelt göra en Putin och få tillbaka makten i sina händer. (http://www.expressen.se/nyheter/erdogans-maktplan-vill-gorasom-putin/, 29.4.2016)

Ilmaus on kuitenkin kotoutettu suomen rakennesääntöjä noudattavaksi jo olemassa olevan mallin mukaan. ${ }^{3}$ Siinä missä idiomaattisuus merkitään englannissa ja ruotsissa erisnimen edessä olevalla odotuksenvastaisella epämääräisellä artikkelilla, suomessa vastaava idiomaattisuuden merkitsin on erisnimen monikkomuoto. Vastaavanlaisia monikollisia ilmauksia on käytetty suomessa jo varhemmin. Esimerkiksi ottaa ritolat viittaa Ville Ritolaan, joka voitti 1928 Amsterdamin olympialaisten 5000 metrin juoksun jättäen loppukirissä kilpakumppanit taakseen. Koska muita vastaavia eponyymisiä rakenteita ei tuohon aikaan ole osoitettu esiintyneen, se on mahdollisesti lajissaan ainutkertainen ilmaus, joka on syntynyt jo olemassa olevien idiomien mallin mukaan (vrt. ottaa hatkat tai ottaa pitkät, joiden kaikkien merkitys on suunnilleen sama, 'lähteä pakoon'). Tämän sanonnan ilmestymisaika kieleemme on kuitenkin selvittämättä. Nykyisin näkee kyseisestä kiteytymästä myös produktiivisempia variantteja, kuten tehdä ritolat tai vetää ritolat. Erisnimi on muuttunut appellatiiviksi, joka on edelleen melko yleisesti käytössä juuri edellä mainitun idiomin osana (ks. myös Nenonen 2007b).

Kieliopillista monikkoa käytetään ensisijaisesti useuden merkitsemiseen, mutta kuten Isossa suomen kieliopissa (ISK 2004, \$1732) todetaan, suomen kielessä monikkomuotoa voidaan käyttää myös muissa funktiossa (ks. myös esim. Penttilä 1957, \$ 300; Karlsson 1960, 23-56, 87-101; Ingo 1978, 8-10; Yli-Vakkuri 1986, 61-71). Normista poikkeavaa monikkomuodon käyttöä havainnollistavat esimerkiksi kiteytyneet tervehdykset ja hyvästelyt (Päiviä! Hyvät viikonloput! Hyviä vointeja!) tai kehuskelun sävyjä sisältävät ilmaukset (Monet pääkaupunkilaiset ylpeilevät sillä, että tuntevat lontoot, brysselit ja pariisit kuin omat taskunsa) (ISK 2004, \$1732). Monikkoa käytetään myös affektisissa sanonnoissa (vähät välittää) ja voimasanan sisältävissä konstruktioissa (esim. Vitut minä

3 Toisessa tutkimuksessa (Nenonen ym. 2013) keskityimme yhden kansainvälisesti tunnetun presidentin, Barack Obaman, nimen käyttöön eponyymikonstruktiossa suomessa ja englannissa. Vertasimme englannin idiomia do an Obama suomen vastaavaan idiomiin tehdä Obamat. Havaitsimme, että puhujat käyttivät runsaasti erilaisia tilanteisia merkitysvariaatioita molemmissa kielissä. Useimmat merkityksistä liittyivät politiikkaan, mutta myös mikä tahansa muu julkisuuden ilmiö kelpasi, kunhan se soveltui kontekstiin. Jotkin merkitykset ovat salientimpia kuin muut, eli niihin viitattiin useammassa idiomissa. Esimerkiksi liki neljäsosa Obama-idiomeista viittasi molemmissa kielissä Obaman vaalivoittoon altavastaajana. Suomen idiomilla viitattiin usein kuitenkin myös kotimaan politiikkaan, kun verrattiin Obaman vaalivoittoa Suomen 2012 presidentinvaaleihin. Tässäkin mielessä lainaidiomit kotoutetaan omaan kieleen. 
mikään viisas olen! Paskat minä mitään voinut tehdä, ks. esim. Kotilainen 2007a). Vastaavasti myös paljoksuntaa voidaan monikon sijaan ilmaista yksikön partitiivilla (On leipomiseen tarkoitettua muottisarjaa, on isää, äitiä, autoa, taloa; löytyy koiraa, kissaa ja lasta) (ISK 2004, \$1733). Kaikissa näissä normista poikkeavissa tapauksissa voidaan ajatella, että logiikka toimii samoin: kieliopillisen muodon odotuksenvastaisella käytöllä osoitetaan, että kyse on muusta kuin kirjaimellisesta merkityksestä. Tätä havainnollistaa Valma Yli-Vakkurin $(1986,2)$ toteamus, että ilmauksen viestinnällinen arvo, sen informaatiopitoisuus, lisääntyy, kun rikotaan varsinaista kieliopillista normia (esimerkiksi käytettäessä monikkoa viittaamassa kieliopillista yksikkömuotoa edellyttävään referenttiin). Ilmaus on tällöin tyylillisesti tunnusmerkkinen, erottuvampi eli salientimpi kuin norminmukaisesti käytettäessä. Epätyypillisesti käytettävää monikkoa voikin suomessa hyvällä syyllä sanoa idiomaattisuuden indeksiksi, perustuuhan idiomaattisuus nimenomaan odotuksenvastaisuuteen (Niemi ym. 1998; Nenonen-Niemi 2004; 2010). On myös mahdollista, että monikkomuoto saa lisämotivaatiota siitä, että konstruktion kuvaama teko voidaan toistaa ja että tekijöitä voi olla eri kerroilla useita. Kyse ei tällöin olisi yksittäisestä teosta, vaan pikemmin teon tyypistä.

Tämän artikkelin tarkoitus on havainnollistaa, miten moniulotteista ja rikasta merkitysten kirjoa voidaan välittää eponyymisilla verbilausekekonstruktioilla. Konstruktion merkitystä täsmentää kuhunkin yksittäiseen ilmaukseen sisällytetty erisnimi, joka yksilöinnin sijaan toimii pikemminkin kuvaavassa ja kontekstualisoivassa funktiossa. Analysoimme tässä pelkästään henkilönnimen sisältäviä konstruktioita. Aineistona olemme käyttäneet Google-hakuja ja Kielipankin Suomi24-verkkoaineistoa, joista kerättyjen esimerkkien luokittelu perustuu niihin tilanteisiin merkityksiin, joita ilmaukset kussakin kontekstissa sisältävät. Seuraavassa luvussa perehdytään tarkemmin eponyymisen konstruktion käsitteeseen. Luvussa 3 esitellään aineisto ja analyysimenetelmät. Luku 4 jakautuu kolmeen alalukuun, joissa tarkastellaan luokittelemiemme merkitysten jakautumista alaryhmiin: poliittisiin tekoihin, yksittäisiin tapahtumiin ja presidenttien habitukseen.

\section{Eponyyminen konstruktio}

Kutsumme tässä tutkimuksessa tarkasteltavaa tehdä-verbin ja monikollisen erisnimiobjektin sisältävää rakennetta eponyymiseksi ${ }^{4}$ verbilausekekonstruktioksi, kuten Herbert J. Clark ja Richard J. Gerrig tutkimuksessaan (1983; ks. myös Rapp-Gerrig 1999). Ilmaustyypin konstruktioluonne näkyy sen merkityksessä. Vaikka konstruktion toteuttavat yksittäiset ilmaukset voivat käyttökontekstissaan saada hyvinkin erilaisia merkitysvivahteita, on itse

4 Termi eponyymi merkitsee henkilönnimeä, jota on käytetty henkilön, paikan, esineen tms. nimeämiseen (Tieteen termipankki). Esimerkiksi giljotiini on saanut nimensä keksijänsä Quillotinin mukaan, voltti taas italialaisen tiedemies Voltan mukaan. Käytämme termiä eponyyminen tässä tekstissä hieman eri merkityksessä, sillä eponyyminen verbilausekekonstruktio perustuu metonyymiseen merkityssuhteeseen, kun taas varsinainen eponyymi synnyttää kokonaan uuden sanan (Geeraerts 1994, 2478). 
rakenteella oma merkityksensä, joka näkyy myös sen yksittäisissä toteutumissa. Tätä perusmerkitystä täsmentävät konstruktioon sisällytetyt erisnimet. Voidaan siis sanoa, että

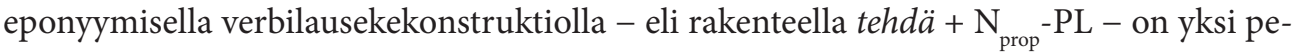
rusmerkitys, joka heijastuu erilaisina tilanteisina erityismerkityksinä, joita kulloinenkin erisnimiobjekti ja sitä ympäröivä konteksti täsmentävät tarkemmin.

Termille verbilausekekonstruktio vaihtoehtoisia nimityksiä ovat formaali idiomi, skemaattinen idiomi tai idiomaattinen konstruktio, joista kahta ensimmäistä on käyttänyt Charles J. Fillmore ym. (1988, 505-506), toista mm. William Croft $(2001,15)$ ja viimeistä Paul Kay ja Charles J. Fillmore (1999; ks. myös Penttilä 2010). Kaikki termit viittaavat idiomaattisiin ilmauksiin, jotka sisältävät sekä leksikaalisesti tarkkaan määrättyjä että leksikaalisesti avoimia osia ja sallivat näin leksikaalista vaihtelua idiomaattisen rakenteen sisällä. Termit kuvaavat ilmiötä kuitenkin eri näkökulmista: kaksi ensimmäistä korostaa konstruktion skemaattista luonnetta, jossa idiomaattisella ilmauksella on osin vakiintunut syntaktinen rakenne, kun taas kolmas painottaa konstruktion idiomaattista luonnetta, eli sitä, että sen rakenne on leksikaalisesti rajoitettu. Paula Sjöblom $(2006,73)$ kutsuukin tarkastelemaamme idiomityyppiä yleisnimityksellä skeema. Lari Kotilaisen (2007a, 21) mukaan ilmausta voidaan myös pitää muottina siinä merkityksessä kuin termi ISK:ssä määritellään (ISK 2004, \$148, \$449).

Käyttämällä tarkastelemastamme ilmiöstä termiä konstruktio kytkemme tarkastelun konstruktionistiseen näkemykseen kielestä. Sen mukaan kielen perusyksikköjä ovat merkityksen ja muodon yhdistävät kieliopilliset rakenteet eli konstruktiot (Fried-Östman 2004, 2; ks. myös esim. Kotilainen 2007a; Hamunen 2017). Konstruktioita ovat kaikki sellaiset kielelliset rakenneyksiköt, jotka eivät ole suoraan pääteltävissä konstruktion rakenneosasista tai muista kieliopillisista konstruktioista (Goldberg 1995, 4; ks. myös Goldberg 2006, 5). Laajuudeltaan, kompleksisuudeltaan ja abstraktiotasoltaan konstruktiot voivat vaihdella suuresti. Suomen kielessä pienimpiä ja yksinkertaisimpia konstruktioita edustavat ei-vapaat morfeemit, kun taas laajimpia konstruktiotyyppejä ovat erilaiset lausetyypit, kuten suomen transitiivilauseen skeema NPNOM + V + NPPART/GEN/NOM (Kotilainen 2007a, 17). Konstruktioon liittyy konventionaalisuus, joka mahdollistaa sen, että rakenne on helppo aktivoida käyttöön suhteellisen automaattisesti, ilman että sen osiin tai niiden järjestykseen tarvitsee kiinnittää erityistä huomiota (vrt. Langackerin 1987, 494 määritelmä kielen yksikölle). Suomen kielen konstruktioita on kirjallisuudessa käsitelty varsin monipuolisesti. Tarkastelussa ovat olleet muun muassa verbikonstruktiot sekä ensimmäisessä raamatunkäännöksessä (Leino ym. 2001) että yleisemminkin (Herlin \& Kotilainen 2012), erilaiset infiniittiset konstruktiot (Herlin-Visapää 2005; Hamunen 2017, 2018), kirosana- ja kieltokonstruktiot (Kotilainen 2007a, 2007b) sekä onomatopoeettiset imitatiivikonstruktiot (Jääskeläinen 2013).

Konstruktionistinen näkemys sopii eponyymisen verbilausekekonstruktion tarkasteluun myös siksi, että siinä ei määritellä ennalta, millaiset rakenteet ovat kielen kannalta perus- tai ydinrakenteita ja millaiset marginaalisia. Näin esimerkiksi idiomaattisia rakenteita, jollainen eponyyminen verbilausekekonstruktiokin on, ei pidetä kieliopillisen 
kuvauksen kannalta toissijaisina, vaan produktiivisten ilmausten ja idiomien välinen suhde nähdään pikemminkin jatkumona suhteellisen produktiivisten ja suhteellisen jähmeiden konstruktioiden välillä. (Fried-Östman 2004, 16.) Vaikka kytkemme tarkastelumme konstruktionistiseen näkemykseen kielestä, emme tässä artikkelissa sovella erilaisissa konstruktiokieliopin suuntauksissa käytettyjä formaaleja kuvausmalleja, joiden eroja ja yhtäläisyyksiä Jaakko Leino (2010) erittelee ansiokkaasti. Sen sijaan keskitymme havainnollistamaan niitä merkityksiä ja käyttökonteksteja, joissa tarkastelemamme ilmiö esiintyy.

Rakenteeltaan eponyyminen verbilausekekonstruktio on verbilauseke, jonka ensimmäisenä osana on verbi tehdä ja sen objektina monikkomuotoinen erisnimi, jolla viitataan kyseiseen nimeen kytkeytyvään ominaisuuteen, tekoon tai toimintaan. Objektin paikalla oleva erisnimi ei siis toimi varsinaisena erisnimenä eli proprina, joka yksilöi nimenkantajan, mitä on perinteisesti pidetty erisnimen keskeisenä tehtävänä (Ainiala-Saarelma -Sjöblom 2008, 12-13). Pikemminkin nimi tässä konstruktiossa toimii appellatiivistuneena homonyyminä, jonka merkitys on metonyyminen ja viittaa varsinaisen erisnimen kantajan sijasta nimeen kytkeytyvään ilmiöön. Tämä näkyy myös siinä, että kirjoitetussa tekstissä nimi voi olla yhtä hyvin isolla kuin pienellä alkukirjaimella kirjoitettu. Merkitys on siis vastaava kuin lauseessa Museoon on ostettu uusi Picasso, jossa nimi Picasso tarkoittaa 'Picasson tekemää taideteosta', eikä taiteilijaa itseään. (Sjöblom 2006, 52, 73; ks. myös Mikkonen 2003.) Appellatiivistunut erisnimi toimii tällöin ideationaalisessa funktiossa ja ilmauksen ymmärtäminen edellyttää ensyklopedista merkitystulkintaa (Halliday-Matthiessen 2004, 29; Sjöblom 2006, 70; nimien monista funktioista ks. Sjöblom 2006, 68-71).

Eponyyminen verbilausekeidiomi tehd $\ddot{a}+\mathrm{N}_{\text {prop }}-\mathrm{PL}$ on sikäli tyypillinen suomen kielen idiomi, että se koostuu yleisestä verbistä ja taivutetusta nominista (Nenonen 2002; 2007a). Verbi voi konstruktiossa myös vaihdella: muita mahdollisuuksia ovat esimerkiksi vetää, heittää, käydä, tapahtua (esimerkit 8-9). Toisinaan idiomi esiintyy myös negaatiossa, jolloin objekti on monikon partitiivissa. Monikon partitiivi voi esiintyä myös myöntölauseessa aspektiltaan rajaamattomissa ilmauksissa tai kysymyslauseissa (esimerkit 10-11).

(8) Soinille kävi kekkoset tai ceausescut. Liian kauan vallassa. (http:// hommaforum.org/index.php?topic=105704.300)

(9) USA' ssa voi nyt myös tapahtua "haloset, ja valtio saa ensimmäisen naispresidentin. (http://ilkkaluoma.puheenvuoro.uusisuomi.fi/213353trump)

(10) Harvemmat kumminkaan yksityisellä helikopterilla tekevät Räikkösiä, varmaan kun ei ole rahaa tommoseen. (https://keskustelu.suomi24. fi/t/8342462/vitun-rallit!)

5 Myös englannissa eponyymisen verbilausekekonstruktion verbi voi vaihdella. Mahdollisia verbejä ovat do-verbin lisäksi ainakin perform ja pull (Rapp-Gerrig 1999, 613). 
(11) Näkyi nyt kirjoittaneen faceen: "Onko kukaan tehnyt Hitlereitä Suomessa? https://keskustelu.suomi24.fi/t/14663255/miksi-vain-yksi-asiakielletty

Eponyymiset konstruktiot ovat Clarkin ja Gerrigin $(1983,592-3)$ mukaan kontekstuaalisia ilmauksia, joiden merkitys täytyy luoda (vrt. polyseemiset ilmaukset, joiden merkitys täytyy valita kontekstin antamien vihjeiden pohjalta). He toteavatkin, että vaikka englannin do an $N_{\text {prop }}$-konstruktio on jokapäiväinen ilmiö kielessä, sen yksittäiset esiintymät harvoin konventionaalistuvat leksikkoon, koska kunkin yksittäisen ilmauksen erityismerkitys on luotava itse tilanteessa. Konventionaalistuminen on kuitenkin mahdollista, ja Fillmore ym. $(1988,506)$ toteavatkin formaaleista idiomeista, että ne voivat toimia metarakennetyyppisenä "isäntänä" vakiintuneille idiomeille. Esimerkkinä tästä käy vaikkapa englannin the more the merrier, joka on vakiintunut idiomiksi mutta noudattaa konstruktion the X-er the Y-er -rakennetta. Vastaavasti englannissa myös osa do an $N_{\text {prop }}$-konstruktiota noudattavat idiomit ovat sen verran konventionaalistuneita, että niitä löytyy myös useista slangisanakirjoista. Esimerkiksi CDS listaa 10 ja DSUE kuusi idiomia, jota noudattavat konstruktion rakennetta. Tällaisia ovat esim. do a Houdini, do a Gloria Gaynor ja do a Hank Snow. Suomen kielen sanakirjoista konstruktiota ei löydy lukuun ottamatta Heikki ja Marjatta Paunosen Stadin slangisanakirjaa (2000), jossa tehdä-hakusanan alla esiintyy kaksi tunnetun henkilön nimeä eponyymisessa konstruktiossa, $N y k \ddot{a}-$ nen ja Kononen. Edellinen on mäkihyppääjä Matti Nykäsen nimeä kantava idiomi, tehdä nykäset, jonka merkitys on yleisluotoinen 'toilailla jonkun julkisuuden henkilön tavoin'. Tehdä konoset 'oksentaa', puolestaan viittaa yksittäiseen tapaukseen, kilpakävelijä Valentin Konosen 50 km EM-kävelykisaan Helsingissä 1994. Kononen joutui tyhjentämään imeytymättömän nesteytyksen oksentamalla samaan aikaan kun jatkoi kävelemistä. Lisäksi sana-artikkelissa on esimerkkinä tehdä eetvartit (eedvartit) 'luopua', jonka alkulähteestä kirjoittajilla ei ole tietoa.

Clark ja Gerrig $(1983,594)$ ovat muotoilleet do an $N_{\text {prop }}$-konstruktion keskeisen merkityksen seuraavasti: ilmauksella viitataan toimintaan, jonka sekä puhuja että kuulija voivat ainukertaisesti identifioida jotenkin silmiinpistäväksi toiminnaksi ilmauksessa mainitulle eponyymille (ks. myös Penttilä 2006, 80-81). Se, mitä milloinkin pidetään tällaisena toimintana, on hyvin tilannesidonnaista ja voi vaihdella samankin eponyymin osalta kontekstin vaihdellessa, mitä esimerkit 12 ja 13 havainnollistavat. Olennaista on, että sekä puhuja että kuulija jakavat tiedon siitä, millaiseen toimintaan kussakin tilanteessa viitataan.

(12) Do a Napoleon for the camera 'pose with your hand tucked in your vest'; do a Napoleon 'tehdä napolenit, poseerata käsi liivin povitaskussa'.

(13) The Shah of Iran did a Napoleon to an island off Panama in 1980; do a Napoleon 'tehdä napoleonit, lähteä maanpakoon'. (Clark-Gerrig 1983, 594-595)

Erisnimen ei välttämättä tarvitse olla henkilönnimi. Myös esimerkiksi paikannimi, valtionnimi tai vaikkapa radiokuunnelman nimi voivat olla konstruktion osana, kuten 
englanninkielisissä esimerkeissä 14 ja 15. Esimerkissä 15 on mukana myös henkilönnimi, mutta tässä tapauksessa se toimii vain etumääreenä varsinaiselle eponyymille, joka on kuulu radiokuunnelma War of the Worlds. Samaan tapaan myös suomessa eponyymikonstruktion erisnimi voi olla vaikkapa valtionnimi tai elokuvan nimi, kuten esimerkeissä 16 ja 17 (ks. myös Karlsson 2000, 101).

(14) He didn't think that the US would do a Suez in the Middle East (BNC2 $\mathrm{BoH} 1033)^{6}$ 'tehdä Suezit, lisätä poliittista vaikutusvaltaa ulkomailla'

(15) Before you think, 'Oh, it's only Tarrant trying to do an Orson Welles War Of The Worlds on us', I have to tell you-it's true. ( $\mathrm{BNC}_{2} \mathrm{CH}_{2}$ 2042) 'tehdä Orson Wellesin Maailmojen sodat, yrittää huijata ihmiset uskomaan, että joku fiktiivinen asia on totta'

(16) Venäjä teki venäjät, nousi viimeisellä minuutilla tasoihin, mutta siinä vaiheessa jo ilman kapteeniaan. (https://muusikoiden.net/keskustelu/ posts.php? $\mathrm{c}=26 \& \mathrm{t}=228898 \& \mathrm{x}=1040,28.4 .2016$.)

(17) Jokunen vuosi sittenhän DC yritti tehdä scifille "vertigot" HELIXotsikolla julkaistuilla tieteissarjiksilla, mutta ainoastaan Warren Ellisin mainio "Transmetropolitan" sai suurempaa suosiota, vaikka hyviä sarjoja pesueeseen mahtui muitakin. (http://www.kvaak.fi/keskustelu/index. php?topic=7090.20;wap2, 29.4.2016.)

Koska konstruktiota toteuttavan yksittäisen ilmauksen merkitys on luonteeltaan tilannesidonnainen, sitä ei aina pysty päättelemään ilman välitöntä kontekstia. Usein tätä erityismerkitystä täsmennetäänkin kertomalla se samassa yhteydessä myös toisin sanoin, kuten esimerkeissä 16-17 yllä tai 18-19 alla. Esimerkki 18 on kommentti Kalevan uutiseen, jossa Yhdysvaltojen yleisesikuntapäällikkö Mike Mullen ja hänen venäläinen virkaveljensä Nikolai Makarov ovat tavanneet Puolustusvoimain komentajan Juhani Kaskealan. Kekkosella oli tunnetusti tapana kutsua arvovieraat kalastamaan ja saunomaan. Esimerkki 19 viittaa siihen, että Tarja Halonen ja Pertti Arajärvi asuivat ennen avioitumistaan vierekkäisissä kerrostalohuoneistoissa.

(18) Toivottavasti kaskeala tekee Kekkoset ja vie poijjaat saunoon ja kalaan! Känni päälle nii unohtuu ne sotimiset. (http://www.kaleva. fi/uutiset/kotimaa/usan-ja-venajan-armeijan-johdolla-tapaaminensuomessa/334358/, 28.4.2016)

(19) aikoinaan työkaverin kanssa juteltiin avioliittoinstituutiosta, hän oli sillä kannalla että ainoa mahdollisuus onnistua olisi tehdä haloset että asuttaisiin viereisissä huusholleissa. (http://kaksplus.fi/keskustelu/ plussalaiset/mitas-nyt/2094987-kaksi-yh-aitia-muuttavat-lastensa-kanssakimppaan-mielipiteita/, 28.4.2016)

$\overline{6 \text { Esimerkit } 14}$ ja 15 ovat peräisin British National Corpuksesta (BNC). 
Seuraavassa luvussa esittelemme tarkemmin käyttämämme tutkimusaineiston, josta myös kaikki yllä esitetyt presidenttiviitteiset esimerkit on poimittu. Vain eponyymistä konstruktiota havainnollistavat englanninkieliset esimerkit on poimittu varsinaisen aineistomme ulkopuolisista lähteistä.

\section{Tutkimusaineisto}

Tähänastisissa tutkimuksissa maininnat suomen eponyymisesta konstruktiosta rajoittuvat hajanaisiin havaintoihin ilmiön ympäriltä: on muun muassa esitetty huomioita siitä, kuinka ilmaukseen sisältyvän nimen monikkomuoto toimii idiomaattisuuden merkitsijänä (Niemi ym. 1998, 295) tai miten konstruktion yleinen merkitys muodostuu ja millaisessa ortografisessa muodossa se kirjoitetussa tekstissä esiintyy (Karlsson 2000; Nenonen 2007a, 323). Tästä syystä päätimme poimia esimerkkejä tarkasteluun systemaattisesti tietystä aihepiiristä. Koska julkisuuden henkilöistä, kuten poliitikoista, käytetään runsaasti eponyymisia idiomeja, valitsimme kohteeksi kaikki tähänastiset Suomen presidentit, joiden nimistä olemme tehneet hakuja Kielipankin Suomi24 2016H2-korpuksessa (sisältää Suomi24-keskustelupalvelun keskustelut 1.1.2001-24.9.2016) sekä internetistä Googlehakukoneella vuonna 2013 ja uudelleen vuonna 2018. Googlen hakulauseessa käytettiin erisnimeä monikon nominatiivissa ja partitiivissa ja tehdä-verbiä eri aika- ja persoonamuodoissa (esim. tehdä/teki/tekee "Ahtisaaret/ahtisaaret"/"Ahtisaaria/ahtisaaria"). Kielipankin Suomi24-korpuksessa haettiin Korp-konkordanssihakuohjelman (Borin-Forsberg-Roxendal 2012) avulla niin ikään monikon nominatiivissa ja partitiivissa olevia presidentinnimiä lauseista, joissa oli myös tehdä-verbi. Presidentit valitsimme siksi, että heidän nimensä ovat yleisesti tunnettuja, ja ennen kaikkea siksi, että Suomen tasavallan presidenttejä on tietty määrä, joten aineisto on helppo rajata. Oletettavasti itsenäisyyden alkuvuosien presidenteistä ei tämäntyyppisiä sanontoja nykyään juuri käytetä, mikä näkyykin aineistossamme.

Kaiken kaikkiaan keräsimme 299 osumaa $^{7}$, jotka sisältävät tehdä-verbin ja monikossa olevan presidentinnimen. Ilmausten kirjoitusasu vaihtelee. Konstruktion erisnimessä voidaan käyttää joko isoja tai pieniä alkukirjaimia, esim. tehdä kekkoset, tehdä Kekkoset. Vajaa puolet (147/299) keräämistämme idiomeista oli kirjoitettu isolla alkukirjaimella, mutta mitään erityistä käytäntöä kirjoitusasun valinnassa ei näyttäisi olevan. Myös koko nimeä näkee toisinaan käytettävän, esim. tehdä Urho Kekkoset. Toisinaan käytetään myös lainausmerkkejä, esim. tehdä "Kekkoset". Nimen voi kirjoittaa myös kokonaan yhteen, tehdä urhokekkoset. Myös muita variaatioita esiintyy, etenkin Kekkosen ja Niinistön nimien käytössä, esim. tehdä urkit/Urkit/UKK:t; tehdä saulit/salet. Myös etu- ja lempinimistä tehdyt idiomit otettiin laskelmiin mukaan, sikäli kun niitä löytyi. Taulukossa 1 esitetään

7 Googlesta saimme kaikkiaan 222 osumaa ja Suomi24-korpuksesta 96. Esimerkeistä 19 esiintyi molemmissa aineistoissa. 
Taulukko 1. Suomen presidentin nimen sisältävät eponyymikonstruktiot.

$\begin{array}{lll}\text { Presidentti } & \text { vv. } & \text { Osumia } \\ \text { Sauli Niinistö } & 2012- & 92 \\ \text { Tarja Halonen } & 2000-2012 & 33 \\ \text { Martti Ahtisaari } & 1994-2000 & 37 \\ \text { Mauno Koivisto } & 1982-1994 & 25 \\ \text { Urho Kekkonen } & 1956-1982 & 89 \\ \text { J. K. Paasikivi } & 1946-1956 & 6 \\ \text { C. G. Mannerheim } & 1944-1946 & 5 \\ \text { Risto Ryti } & 1940-1944 & 11 \\ \text { Kyösti Kallio } & 1937-1940 & 1 \\ \text { P. E. Svinhufvud } & 1931-1937 & 0 \\ \text { L. K. Relander } & 1925-1931 & 0 \\ \text { K. J. Ståhlberg } & 1919-1925 & 0 \\ \text { yht. } & & 299\end{array}$

poimittujen idiomien lukumäärät. Kuten taulukosta näkyy, varhaisempien presidenttien nimiä ei eponyymikonstruktioissa juuri esiinny.

On luontevaa, että rakenteeseen sisältyvän verbin ja sen objektin välissä voi toisinaan olla esimerkiksi adverbiaaleja. Useimmiten konstruktiot olivat tekstissä yksinkertaisina lausekkeina, mutta jonkin verran niitä on myös muokattu, yleisimmin adverbin avulla (31 tapausta), kuten esimerkissä 20. Viisi kertaa oli käytetty myös adjektiivia (esim. 21-22), vaikka idiomin sisäinen modifiointi eli adjektiivin käyttö rakenteen sisällä onkin yleensä verrattain harvinaista (Nicolas 1995; Heinonen 2013, 42). Kuten Tarja Riitta Heinonen $(2013,42)$ toteaa, idiomeissa voi olla vapaita paikkoja substantiivien etumääreille ja adverbeille. Nämä määreet voivat olla merkitykseltään neutraaleja, kuten esimerkin 21 maailmanlaajuiset, joka toimii pikemminkin adverbin tapaan (maailmanlaajuisesti) määrittäen koko lausetta. Määreet voivat olla myös tunnusmerkkisiä, kontekstista riippuvaisia, kuten esimerkin 22 lakeerikengättömät, joka juontaa juurensa Ahtisaaren runsaasti uutisoituun liukkaista lakeerikengistä aiheutuneeseen kaatumiseen vierailulla Ruotsin kuninkaanlinnassa 1994 .

(20) Äänestän Soinia nimenomaan sen takia, että hän varmistaa sen, etteivät tyhjäpäät pääse 2. kierrokselle tekemään toistamiseen halosia. [Halonen voitti Niinistön toisella kierroksella vuonna 2006 vaaleissa.] (https:// keskustelu.suomi24.fi/t/10359643/kumpaa-aanestaisin--essayjahia-vaisoinia-, 10.1.2012.) 
(21) Minusta pitäisi tehdä maailmanlaajuiset Kekkoset: halata kuoliaaksi Ostrobotnian puheilla radikaali vasemmisto, integroida se yhteiskuntaan, eli päästää Perussuomalaiset hallitukseen kuten Kekkonen teki Vennamollekin, tehdä toisin kuin Ruotsi omille "demokraateilleen". (http:// www.justhelminen.fi/364541860/2444030/posting/, 28.4.2016.)

(22) Koiran kanssa liikkuessa meinasin kahdesti tehdä lakeerikengättömät marttiahtisaaret ja kun näin, miten Pappilankorven teollisuusalueen bussivarikolta tulevat bussitkin olivat ongelmissa noustessaan loivaan ylämäkeen kohti Hanko-Hyvinkää-radan tasoristeystä, tulin siihen päätelmään, että Laihon ukko vaimon kera ei hengissä töihin selviä niillä semi-Kekkosilla ${ }^{8}$, jotka autossa olivat alla. (http://www.finwx.net/forum/ index.php?topic=3310.65; wap2, 28.3.2019.)

Esimerkki 22 havainnollistaa hyvin myös sitä, miten konstruktion yhteydessä käytetty määre voi täsmentää ilmauksen ymmärtämiseen tarvittavan kontekstin johonkin puhehetken ulkopuoliseen tilanteeseen. Tämä taas mahdollistaa vastaanottajalle ilmauksen tulkinnan - edellyttäen tietysti, että kyseinen tilanne on myös vastaanottajalle tuttu. Myös edeltävä konteksti, jossa käytetään E-infinitiivin inessiiviä liikkuessa, tarjoaa vihjeen tulkinnasta yhdessä lakeerikenkien kanssa.

\section{Merkitysten jakautuminen}

Käsittelimme idiomit yksi kerrallaan ja päättelimme kontekstin perusteella kunkin ilmauksen erityismerkityksen, mikäli se oli mahdollista. Luokittelimme tämän jälkeen konstruktiot niiden kontekstista pääteltävän merkityksen mukaan. Lopputulokseksi saimme 299 ilmaukselle kaikkiaan 123 erilaista tilanteista erityismerkitystä (näiden lisäksi viiden idiomin merkitystä ei voinut jäljittää). Esimerkiksi ilmaus tehdä kekkoset voi tilanteen mukaan merkitä 'olla korvaamaton', 'erottaa hallitus' tai 'kiivetä palmuun noottikriisin aikaan'. Idiomeista 83 on erityismerkitykseltään ainutkertaisia, kun taas kolme tilannesidonnaista merkitystä esiintyi vähintään 20 kertaa (tehdä Niinistöt 'ottaa itseään huomattavasti nuorempi puoliso', tehdä Niinistöt/Haloset/Ahtisaaret 'pienentää omaa palkkiotaan' ja tehdä Kekkoset 'tulla valituksi aina uudestaan'). Kaikki aineistosta määritellyt tilannesidonnaiset erityismerkitykset on listattu liitteessä 1 .

Aineistossamme olevien idiomien tilanteiset merkitykset jakautuivat luontevasti kolmeen ryhmään, (i) politiikkaan, (ii) yksityiselämään liittyviin tapauksiin ja (iii) presidenttien habitukseen. Habituksella tarkoitamme tässä henkilön ulkomuodon lisäksi myös elämäntyyliin ja persoonallisiin tapoihin liittyviä piirteitä bourdieaulaisessa mielessä (ks. esim. Gronow 2012). Kaksi kolmasosaa (67\%) merkityksistä liittyy politiikkaan

8 Tässä viitataan Kekkosen kaljuun; loppuun kuluneita autonrenkaita saatetaan toisinaan kutsua kekkosiksi tai Kekkosiksi. 
(poliittinen teko 133 esiintymää, vaaleihin liittyvä merkitys 70 esiintymää). Esimerkiksi Sauli Niinistö palautti osan palkastaan (17 esiintymää) ja Urho Kekkonen säilytti asemansa presidenttinä 25 vuoden ajan (21 esiintymää). Noin viidesosa ( $22 \%)$ liittyy presidenttien ulkoiseen olemukseen tai heidän luonteeseensa tai muihin leimallisiin piirteisiinsä. Kekkonen oli kalju ( 5 esiintymää) ja Ahtisaarella on lonkkavika, joka vaikuttaa hänen kävelytyyliinsä ( 3 esiintymää), kun taas Niinistö meni naimisiin itseään nuoremman naisen kanssa ( 23 esiintymää). Loput 10 prosenttia liittyvät yksittäisiin tapauksiin presidenttien elämässä: Kekkonen kiipesi Tunisian-matkallaan palmuun vuonna 1964 ja tuli kuvatuksi televisioon ${ }^{9}$ (7 esiintymää), Ahtisaari ja Kekkonen kompastelivat toisinaan syystä tai toisesta (11 esiintymää). Liitteessä 2 esitetään skemaattinen jaottelu yksittäisten ilmausten tilannesidonnaisista merkityksistä aineistossamme.

\subsection{Poliittiset teot}

Kuten taulukosta 1 näkyy, aikaisemmista presidenteistä ei haussamme löytynyt osumia, lukuun ottamatta Kalliota, Rytiä, Paasikiveä ja Mannerheimia, joiden vaikutus Suomen historiaan on edelleen yleisessä muistissa, joten ilmaus on mahdollista tulkita kontekstissaan. Kyösti Kallio esiintyy yhden kerran (esim. 23). Esimerkki viittaa Kallion itsenäisyyspäivän radiopuheeseen viikko talvisodan syttymisen jälkeen vuonna 1939. Puheessaan hän lausui kuuluisan rukouksen isänmaan puolesta. Risto Ryti esiintyi kaikkiaan 11 kertaa, joista valtaosaa (9 esiintymää) käytettiin samassa merkityksessä: vuonna 1944 Ryti luovutti paikkansa Mannerheimille ja otti yksin vastuun Saksan kanssa liittoutumisesta, jotta rauhansopimus Suomen ja Neuvostoliiton välillä saatiin aikaan (esim. 24). Juho Kusti Paasikivi taas muistetaan erityisesti 1948 solmitusta YYA-sopimuksesta Neuvostoliiton kanssa (esim. 25).

(23) Ehdotan että tehdään Kyösti Kalliot ja rukoillaan Suomen puolesta normaalin ruohonjuuritasotyöskentelyn lisäksi jos nyt rehellisiä ollaan. (https://hommaforum.org/index.php?topic=108965.0)

(24) Toisaalta Katainen voi tehdä ns. rydit. Astumalla sivuun Katainen vapauttaa puolueen omasta RKP-sitoumuksestaan. (https://keskustelu. suomi24.fi/t/11558522/valtamedia-hadissaan-gallupista-rkpn-takia)

(25) Nyt kun maassa on presidenttinä moskovan juoksupoika, on tärkeää että sosialistit vahtivat valtion taloutta ja omistajuutta. Niinistö voi nimittäin yrittää tehdä Paasikivet ja myydä maan Putinille saadakseen toisen kauden. (http://keskustelu.kauppalehti.fi/5/i/keskustelu/thread. jspa?messageID $=5622187$ )

Idiomien perusteella voi päätellä, että Ryti ja Paasikivi muistetaan poliittisista teoistaan, kun taas Mannerheim, joka äänestettiin 2004 Yleisradion Suuret suomalaiset -kilpailussa

9 https://www.youtube.com/watch?v=EdW1gJVip5w, katsottu 10.6.2019 
Suomen historian merkittävimmäksi henkilöksi, on puolestaan kirvoittanut erillisiin tapauksiin liittyviä monenlaisia merkityksiä, sillä esiintymät poikkeavat tilannesidonnaiselta merkitykseltään toisistaan. Esimerkki 26 viittaa Mannerheimin viimeisiin vuosiin Sveitsissä. On esitetty teorioita, että Mannerheim olisi lähtenyt ulkomaille välttääkseen sotaoikeudenkäynnin, mutta virallinen selitys on, että hän lähti heikon terveytensä takia. Samaan tapaukseen viitataan suoraan esimerkissä 27. Esimerkin 28 merkitys taas selviää tapahtumaketjusta, jonka mukaan talvisodan edellä Mannerheim olisi halunnut tehdä Neuvostoliitolle myönnytyksiä, jotta Suomi olisi ehtinyt varustautua sotaan kunnolla. Mannerheim kritisoi hallituksen optimismia ja uhkasi erota tehtävistään, mutta punaarmeijan hyökättyä hän suostui ryhtymään ylipäälliköksi.

(26) Putin teki mannerheimit eli lähti Sveitsiin hoitamaan terveyttään. (https://keskustelu.suomi24.fi/t/13484276/putin-sai-lapsen-no-huh-huhsentaan)

(27) ja ellei fasistit olisivat olleet niin nopeita käänteissään, olisi Hortnykin tehnyt "Mannerheimit" eli livistänyt sodasta häntä koipien välissä. (http://lievemaa.puheenvuoro.uusisuomi.fi/2009/11/28/kommunistisetsymbolit-kiellettiin-puolassa)

(28) 28. V 1937 tapahtui vähemmän tunnettu episodi, kun Nenonen erään oman virkansa toimenkuvaa koskevan pitkäaikaisen kiistan aikana teki Mannerheimit eli uhkasi erolla, jos hänen näkemyksiään ei hyväksytä. (https://maanpuolustus.net/threads/käytöstä-poistettujen-vermeidenmuistelua.4897/page-15)

Urho Kekkonen, joka on ollut pitkäaikaisin presidenttimme, muistetaan edelleen hyvin, vaikka hänen presidenttikautensa päättyi jo yli 30 vuotta sitten. Tämä näkyy myös eponyymisten kekkosidiomien runsautena. 89 kekkosidiomia sai luokituksessamme peräti 33 erilaista tilannesidonnaista erityismerkitystä. 63 esiintymää liittyi politiikkaan tai vaaleihin, 17 politiikan ulkopuolisiin tapauksiin ja 9 hänen ulkomuotoonsa tai luonteeseensa. Vuoden 1961 noottikriisiin viitataan esimerkissä 29, jossa arvellaan Kekkosen tilanneen nootin Neuvostoliitosta itse varmistaakseen jatkokauden itselleen presidenttinä. Kotimaan politiikkaan taas viitataan esimerkissä 30, joka viittaa pääministeri Kekkosen pyrkimykseen nujertaa veturimiesten lakko vuonna 1950 voimakeinoin. Toisin kuin esimerkin kirjoittaja olettaa, Kekkonen kuitenkin perui kertausharjoitussuunnitelmansa ennen kuin se pantiin täytäntöön.

(29) Bush tekee Kekkoset. Kekkonen järjesti 1961 Noottikriisin, ja varmisti jatkopaikan presidenttinä. G.Bush lavastaa terroristi-iskun USA:han. Tarmokkailla toimenpiteillä Bush torjuu tämän terroristi hyökkäyksen, ja varmistaa jatkopaikan presidenttinä. (http://yle.fi/vintti/yle.fi/yleradio1/ viewtopica $9 \mathrm{~b}-2 \cdot \mathrm{html} ? \mathrm{f}=2 \& \mathrm{t}=1080 \& \mathrm{sid}=220 \cos 219 \mathrm{ae} 2 \mathrm{ca} 851 \mathrm{fb} 70 \mathrm{co} 5988$ eaf1) 
(30) Olisi aika tehdä "kekkoset", eli kutsua paperityöläiset kertausharjoituksiin. Kekkonenhan kutsui lakkoilevat veturinkuljettajat kertausharjoituksiin ja sitten komennettiin ajamaan vetureita päivärahalla. Johan loppui turha lakkoilu äkkiä. (https://keskustelu.suomi24.fi/t/1765995/ paperiliitonlakko-vs-veturimiestenlakko)

Kekkosen toistuvaan uudelleenvalintaan on viitattu usein, olihan hän presidenttinä peräti neljä kautta peräkkäin. Esimerkeissä 31 ja 32 verrataan Venäjän presidentti Vladimir Putinia ja keskustapoliitikko Paavo Väyrystä tässä suhteessa Kekkoseen. Uransa loppuvaiheissa presidentti Kekkonen ei ollut enää työkykyinen sairautensa vuoksi, mutta tämä salattiin ja Kekkosta pidettiin vallassa, kunnes hän pyysi eroa virasta vuonna 1981 . Vladimir Putinin puolestaan huhuttiin sairastavan syöpää lokakuussa 2014, mikä herätti kirjoittajan pohtimaan yhtymäkohtia Kekkoseen (esim. 33).

(31) Putin on tehnyt Kekkoset itänaapurissa... Hädin tuskin valittiin muttei lähde pois kulumallakaan kun kansa ja politiikot ovat tottuneet.. (http:// www.kaleva.fi/mielipide/kolumnit/putinismi-on-uusi-nimivanhan-liitonmeiningille/283492/)

(32) Juuri näin, Hemmo, ja säästömielessä, sillä Patehan [Paavo Väyrynen] ei pressaksi päästyään lähde siltä pallilta kulumallakaan, vaan tekee kekkoset ja muut puolueet jatkossa, kansansuosion paineesta, pyytävät poikkeuslailla Patea jatkamaan kahden kauden jälkeen aina siihen asti kun voimia piisaa. (http://hemmokoskiniemi.puheenvuoro.uusisuomi. fi/81081-elakelainen-presidentiksi)

(33) Venäjän hallituksella on siis intressi jatkaa tilannetta mikäli Putin ei pysty tehtäviinsä. Perusta sille, että Venäjä tekee kekkoset on luotu. Jeltsinkin jatkoi kauan presidenttinä vaikka käytännössä hän ei tehtävään kyennyt. (http://maanpuolustus.net/threads/venäjä-vladimir-putinin-jälkeen.3840/)

Mauno Koivistoon viittaavat eponyymiset idiomit liittyvät enimmäkseen politiikkaan. Esimerkissä 34 idiomi viittaa Koiviston aikaan sivussa päivänpolitiikasta ennen presidentinvaaleja, esimerkissä 35 taas strategiapelin pelaaja viittaa Koiviston haluttomuuteen keskustella Neuvostoliiton kanssa Karjalan palauttamisesta Suomelle.

(34) Matti [Vanhanen] tekee Mauno Koivistot ja pressaksi. Maunokin meni sivummalle Suomen pankkiin pois ryvettymsät päivän politiikasta ja sitten palasia puhtoisena pressan vaaleihin Matti meni hetkeksi lepäämään PYL:iin ja palaa sitlä puhtoisen pressan vaaleihin. (http://portti.iltalehti.fi/ keskustelu/showthread.php? $\mathrm{p}=5440659$ )

(35) Jostain syystä ihmisillä on nyt jonkinlainen oletus, että eKarjala olisi minun pääasiallinen tavoitteeni presidenttinä. Tällä linjauksella osoitan oman kantani asiaan, enkä aio tehdä Koivistoja ja jättää tilaisuutta käyttämättä, jos sellainen tulee. (http://www.erepublik.com/en/article/ presidentinvaalit-ovat-ovella-702417/1/20) 
Ahtisaaren poliittinen ura oli lyhyt, yhden kauden mittainen presidentin pesti, johon hänet valittiin mustana hevosena (36). Hän ei lähtenyt ehdokkaaksi toiselle presidenttikaudelle vuoden 2000 valeissa, mitä havainnollistaa esimerkki 37.

(36) Aho olisi voitu vaikka 10 vuoden päästä kaivaa ulos päivänvaloon, ja hän olisi tehnyt Ahtisaaret eli kansalaisten poliitikkovihaa hyväksikäyttäen noussut suoraan korkeimmalle istuimelle. (http://keskustelu.jatkoaika. com/showthread.php?t=7191 \&page $=2$ )

(37) Mitä tulee sitten kahteentoista vuoteen niin saattaa olla, että Niinistö tekee Ahtisaaret, eikä lähde edes toiselle kaudelle. (http://keskustelu.jatkoaika. com/showthread.php? $\mathrm{p}=4005782$ )

Tarja Halonen tunnetaan erityisesti pasifismistaan ja siitä, että on pitänyt usein oman päänsä poliittisissa päätöksissä. Esimerkin 38 katkelma viittaa väitettyyn Suomen Puolustusvoimien alasajoon Tarja Halosen kaudella.

(38) Niinistöhän on muistaakseni korostanut vahvaa presidenttiyttä. Voi siis hyvin tehdä "Haloset" mieleisenä pitämässään asiassa. (http://timouotila. puheenvuoro.uusisuomi.fi/99085-jussi-niinistö-vetosi-sauli-niinistöön)

Sauli Niinistö oli jo ennen presidenttikausiaan näkyvä poliitikko, mm. vuoden 2007 eduskuntavaaleissa kaikkien aikojen ääniharava, mikä näkyy myös kielikuvina, kuten esimerkeissä 39 ja 40.

(39) Osakesäästäjien keskusliiton toimitusjohtaja, professori Jarmo Leppiniemi teki niinistöt. Hän sai 68700 äänestä joka kahdennentoista. Hänestä tuli vaalien ääniharava ja hän veti perässään edustajistoon kolme muuta henkilöä poliittisten listojen ulkopuolelta. (http://www.taloussanomat.fi/ politiikka/2007/06/o2/kolumni-suomen-poliitikot/200713600/12)

(40) Soinin innon tässä tilanteessa ymmärtää, kun heillä ei vaalitukia tullut suuremmin ja puheenjohtaja teki "Niinistöt" ja veti perässään eduskuntaan pari ylimääräistä edustajaa. (http://www.porilaiset.com/ forum/viewtopic.php?f=1\&t=7590)

Vuoden 2012 presidentinvaalien jälkeen puhutti muun muassa presidentti Niinistön ele palauttaa osan palkastaan valtion kassaan (41). Samoin teki myös Yhdysvaltain presidentti Barack Obama vuonna 2013. Niinistö kieltäytyi myös virkamieseläkkeestä (42). "En minä kehtaa, kun en minun mielestäni ole missään eläkeiässä", Niinistö totesi IltaSanomissa ollessaan presidenttiehdokkaana vuonna 2012.

(41) Obama haluaa tehdä niinistöt. Yhdysvaltain presidentti Barack Obama haluaa palauttaa osan palkastaan takaisin valtion kassaan. Näin hän haluaa osoittaa myötätuntoaan julkisen sektorin työntekijöille, joita talouden rajut säästötoimet ovat koskettaneet. (http://www.mtv3.fi/uutiset/ ulkomaat.shtml/obama-haluaa-tehda-niinistot/2013/04/1731552) 
(42) Mitä veikkaat, kuinka moni vihreistä ja vasureista olisi tehnyt Niinistöt(tai on tehnyt), eli jättänyt nostamatta hänelle kuuluvaa isohkoa eläkettä? (http://www.overdrive.fi/forum/viewtopic.php?p=2320128)

Luvussa 4.2 käsittelemme presidenttien elämässä tapahtuneisiin yksittäisiin tapahtumiin viittaavia erikoismerkityksiä. Koska kyse on poliitikoista, raja poliittisen teon ja yksittäisen tapahtuman välillä ei välttämättä ole aina selvä.

\subsection{Yksittäiset tapahtumat}

Kekkoseen liittyvistä yksittäistapauksista yksi muistettavimmista on tapahtuma, jossa 64-vuotias Kekkonen Tunisian-matkallaan kiipesi palmuun (7 esiintymää, ks. esim. 43). Toinen tapaus, josta löytyy useita esimerkkejä, on Kekkosen kaatuminen lentokoneen portaissa (44). Samaan tilanteeseen joutui Suomen jääkiekkojoukkueen valmentaja Pasi Nurminen palatessaan voittoisalta kisamatkalta 2011. Euroopan investointipankin johtajana toiminut Sauli Niinistö puolestaan lomaili Thaimaassa 2004 tapaninpäivän valtaisan tsunamin iskiessä ja pelastautui poikiensa kanssa tarrautumalla sähköpylvääseen (45).

(43) Kai sen Timo P. Niemisen täytyy vielä eläkepäivilläänkin tehdä "kekkoset", kiivetä palmuun ja julistaa sieltä median välityksellä tamperelaisille, kuinka tärkeä Rantaväylän tunneli on kaupunkilaisten hyvinvoinnille. Eihän ne tollot muuten mitään usko. (http://www. rakennuslehti.fi/forum/viewtopic/?did=2531\&page $=1$ \&order $=$ tree)

(44) ja eihän se suomi kuvaaa pilaa jos nurminen tekee "kekkoset" saapuessaaan kotiin miks pitää hävetä jotain mitä ei ite oo tehny ei me siel kaaduttu vaan se oli nurminen! (http://portti.iltalehti.fi/keskustelu// showthread.php?t=516765\&page $=211$ )

(45) Sauli teki "kekkoset" talvella, tsunamin avustuksella. pääsi sähköpaalun nokkaan ilman että tarvi ite kiivetä. (http://keskustelu.suomi24.fi/ node/1642807)

Ahtisaaren kansainvälinen ura rauhanvälittäjänä, jonka kruununa on hänen saamansa Nobelin rauhanpalkinto vuonna 2008, on laajalti tunnettu (46). Hän on ottanut kantaa myös rasismiin, kehottaen kansalaisia osoittamaan vieraanvaraisuutta maahanmuuttajille (47). Ahtisaari ehdotti vuona 2011 MTV3:n 30-vuotisgaalassa, että jokainen suomalainen kutsuisi maahanmuuttajan kahville kotiinsa ja tätä kautta auttaisi sopeutumista suomalaiseen yhteiskuntaan. Esimerkissä 22 esitetty Ahtisaaren liukastuminen Ruotsin kuninkaanlinnassa ja sen näkyvänä merkkinä otsassa oleva laastari herättivät aikoinaan runsaasti huomiota mediassa.

(46) Mieluummin olisin tehnyt Ahtisaaret ja voittanut Nobelin rauhanpalkinnon (http://www.espoonsulkapallo.net/uutiset/ pelaajaprofiili-heikki-vaisanen/) 
(47) Onkohan nuori nainen tehnyt ahtisaaret ja kutsunut kohtaamansa toiseuden edustajan kahville? (http://hommaforum.org/index. php?topic $=80940.5$;wap2)

Sauli Niinistö ja Jenni Haukio salasivat häänsä medialta vuonna 2009, jolloin Niinistö toimi eduskunnan puhemiehenä. Tapaus herätti luonnollisesti mediassa suurta huomiota (48).

(48) Kivoja meilejä on tullut nimittäin eräs hyvä ystävä on tehnyt "Niinistöt", mennyt salaa naimisiin. (http://esteri.vuodatus.net/lue/2009/01/pesukonepelittaa-taas)

Luvussa 4.3 käsitellään presidenttien habituksesta alkunsa saaneita eponyymisia idiomeja. Myöskään raja habituksen ja poliittisen teon tai yksityiselämän tapahtuman välillä ei ole aina selkeä, mutta olemme kuitenkin rajanneet esimerkiksi henkilön koulutustaustan ja kielitaidon habitukseen kuuluvaksi.

\subsection{Habitus}

Mannerheim aloitti sotilasuransa Venäjän keisarillisen armeijan ratsuväessä. Esimerkissä 49 viitataan paitsi Mannerheimin ratsastustaitoihin myös matkaan Aasian halki Kiinaan 1906-1908. Tutkimusretken johtajana toiminut Mannerheim teki matkan kokonaan ratsain. Mannerheimin venäjän kielen taitoon viittaa puolestaan esimerkki 50.

(49) Maapallo alkaa tuntua pieneltä, kun tätä asiaa tarkemmin pohtii. - Jos liika pieneltä tuntuu, niin ainahan voi tehdä "Mannerheimit" ja poiketa Kiinassa ratsastelemassa hepalla. Sitten kun on ratsastanut kiinan vuoriston halki (eihän se Mannerheim ihan non sitä tehnyt), tuntuu se telluskin peijakkaan suurelta paikalta. (https://www.tiede.fi/ comment/392355)

(50) Vois tehdä mannerheimit ja opetella venäjää - varmuuden vuoksi. https:// keskustelu.suomi24.fi/t/10534151/pakenisitko-sodan-syttyessa

Kekkosen ulkoista olemusta kuvaa hyvin hänen leipälapiosta ja silmälaseista tekemänsä omakuva, jossa näkyy kaksi silmiinpistävintä piirrettä, kalju ja vahvat silmälasit. Etenkin kaljuuntumisesta löytyy myös idiomiesimerkkejä (51-52). Esimerkissä 52 mainitaan myös muita harvahiuksisia julkisuuden henkilöitä, joista kukin on tehnyt hiusten lähtöön liittyen hieman erilaisia ratkaisuja. Näitä vauva.fi-keskustelupalstalla sitten ehdotetaan vaihtoehdoiksi kaljuuntumisongelmaan.

(51) Eetu on kehityskelpoinen. moni suurmies on ollut tuollainen nuorena opiskelijana. Ei se ratkaise mitä tekee parikymppisenä, vaan se, onko miestä ottamaan siitä opikseen. - Joo. Vetäytyvästä hiusrajasta päätellen se voi tehdä kekkoset. (http://keskustelut.sub.fi/forum/arkisto/bb-2010yleinen/eetu-on-kehityskelpoinen) 
(52) Vaihtoehtoina on lähinnä tehdä joko urhokekkoset, kimmosasit, immokuutsat tai mauripekkariset. (http://www.vauva.fi/ keskustelu/4487841/ketju/mieheni_kaljuuntuu_peruukki_vaihtoehtona, 2.5. 2016)

Yksi Ahtisaaren silmiinpistävä ominaisuus, lonkkaviasta johtuva huojahteleva kävelytyyli, on ollut seuraavien varsin omintakeisten merkitysten lähteenä. Esimerkissä 53 tulkinta syntyy edeltävän kontekstin pohjalta, kun aluksi puhutaan normaalikuvasta, joka on suora. Esimerkin 54 taloustekstissä taas käytetään liikeverbiä notkahtaa ja liikeverbin nominaalimuotoa heilunta kuvaamassa kurssimuutoksia.

(53) Panasonic TX28PX10:ssä noin on normaalisti normalikuvalla, mutta kirkkaalla kuvalla kuva on suora. Jos asian korjaa, kirkas kuva tekee ahtisaaret. (http://sfnet.viestinta.tv.digi.narkive.com/1KCTRHpj/ thomson-28wm-100-kiero-kuva)

(54) Rumasti notkahtivat Indeksit USAssa. Countrywiden dirikka teki "Ahtisaaret" optioidensa kanssa näemmä. Tulee karvaat muistot mieleen n. 6 v takaa, kun oli jo toimeksianto sisällä Elcon lapuista... Mutta eihän heilunta tähänkään lopu. (http://keskustelu.kauppalehti.fi/5/i/keskustelu/ message.jspa?messageID=2386880)

Tarja Halonen muistetaan paitsi oman päänsä pitämisestä politiikassa (esim. 38 yllä) myös arkisemmasta pukeutumistyylistään ja epäsovinnaisista asusteista virallisissa tilaisuuksissa (55) ja konstailemattomasta asenteestaan presidenttiyteen. Media tavoitti hänet toisinaan ostoksilta marketista (56) tai liikkumasta kadulla kuin kenet tahansa meistä (57).

(55) Saako sandaalien kanssa käyttää sukkia? eiiiiiiiiiiiiiiiii ikänä!!!!!! älä tee halosia ....hyyyyyiiiii!!! (http://www.vauva.fi/keskustelu/307884/ketju/ saako_sandaalien_kanssa_kayttaa_sukkia)

(56) Taidankin tehdä Tarja Haloset ja suunnistaa...Anttilaan! (www.overdrive. fi/forum/viewtopic.php? $\mathrm{p}=347593$ )

(57) Saddam noin vain tekee Haloset ja menee kansansa pariin käppäilemään ex > tempore? (http://groups.google.com/group/sfnet.../ tree/.../543do51ca7eb7f13?)

Kuten julkisuuden henkilöiden elämä yleensä, myös Niinistön yksityiselämä näyttää kiinnostavan kansaa. Peräti neljäsosa (23/92) Niinistön nimen sisältävistä idiomeista viittaa presidenttiparin ikäeroon (58). Sauli Niinistön ja Jenni Haukion naimisiinmenosta v. 2009 on nostettu muitakin ulottuvuuksia, kuten medialta salatut häät (48). Esimerkki 59 sen sijaan viittaa Niinistön rullaluisteluharrastukseen ja poikien isänä olemiseen.

(58) Ahaa, Putin tekee Niinistöt, vaihtaa 30 v nuorempaan! (http://portti. iltalehti.fi/keskustelu/showthread.php? $\mathrm{p}=13754592)$ 
(59) Me miehet päätämme tehdä niinistöt ja pian isä ja poika viilettävät rullaluistimilla pitkin autoilta suljettuja teitä. (http://ellit.fi/ihmissuhteet/ perhe/koti-brysselissa-osa-4-kaksi-luumupuuta-kaksi-kulttuuria)

\section{Lopuksi}

Tässä artikkelissa esitelty analyysi havainnollistaa eponyymisen verbilausekekonstruktion konstruktioluonnetta: konstruktio itsessään sisältää jo vihjeen siitä, että nyt on tarkoitus ilmaista jokin ilmiö tai ominaisuus, joka kytkeytyy konstruktioon sisältyvän erisnimen kantajaan. Lopullisen tilannesidonnaisen erityismerkityksen tarkentavat sitten ilmauksen erisnimi ja konteksti yhdessä. Tässä suhteessa konstruktiossa esiintyvä nimi toimii, kuten nimet yleensäkin, eli on vahvasti kulttuurisidonnainen: sen merkitys syntyy kieliyhteisön ja sitä ympäröivän maailman välisessä vuorovaikutuksessa (Ainiala ym. 2008, 15). Nimet ovat tunteilla ladattuja, mutta yksilöivän ulottuvuutensa takia myös taloudellisia merkityksen ilmaisimia, sillä ne herättävät välittömiä mielikuvia ja assosiaatioita. Tämä tulee hyvin näkyviin tämän konstruktion toteutumissa, jotka tiiviissä muodossa välittävät monenlaisia merkitysvivahteita. (Vrt. mts. 17.) Analyysimme havainnollistaa, kuinka idiomit ovat ikään kuin kielen pikakirjoitusmerkkejä, merkityksen tiivistymiä. Eponyymisen verbilausekekonstruktion lopullinen merkitys purkautuu usein kertomuksen muodossa. Idiomi voi laukaista narratiivin samaan tapaan kuin jotkin metaforat (ks. esim. Ritchie 2017). Kertomukset elävät näissä sanonnoissa. Kekkosella oli tapana viedä vieraansa saunaan ja kalastamaan, missä yhteydessä ratkottiin suuriakin poliittisia kysymyksiä, Martti Ahtisaari puolestaan kehotti kutsumaan maahanmuuttajat kahville, kuten Suomessa kuuluu vieraanvaraisuuden nimissä tehdä.

Eponyymisen verbilausekekonstruktion tilannesidonnaisten erityismerkitysten kirjo on erittäin laaja - näitä idiomeja ei kannata listata sanakirjoihin, koska ne ovat yleensä vahvasti kontekstisidonnaisia. Useimmiten eponyymisia idiomeja käytetään kuitenkin ensisijaisesti päivänkohtaisista asioista puhuttaessa. Presidenteistä puhuttaessa kyseessä ovat ihmiset, joilla on takanaan pitkä julkinen ura täynnä monenlaisia merkittäviä tapahtumia. Niistä yksikään harvoin nousee niin merkittäväksi, että se ylittäisi muut mahdolliset merkitykset, paitsi hetkellisesti jonkin yleistä huomiota herättävän tapahtuman esiin nostamana. Eponyymiset verbi-idiomit syntyvät yhteisistä puheenaiheista, mutta edellyttävät tulkitsijaltaan myös oman kulttuurin tuntemusta ja yleistietoa silloin, kun niissä käytetään julkisuuden henkilöitä. Samaa rakennetta saatetaan kuitenkin käyttää myös niin, että siihen sijoitetaan esimerkiksi perheenjäsenen, työtoverin tai muun sisäpiiriläisen nimi: yhteisön jäsenet tietävät, mitä ilmauksella tarkoitetaan, mutta ulkopuoliselle tämä tilannesidonnainen merkitys ei välttämättä aukene (Clark-Gerrig 1983, 600). Myös luvussa 1 mainitut keskustelupalstojen nimimerkki-idiomit kuuluvat samaan ryhmään. Tällöinkin ilmaukset syntyvät tietyssä tilanteessa, ja mekanismi on sama: eponyymikonstruktio on merkitykseltään konventionaalinen kehikko, sapluuna, johon lisätty erisnimi antaa sille 
sen tilanteisen erityismerkityksen. Tällaisten sisäpiiri-ilmausten merkitystä ei ole yhtä helppo päätellä kontekstin perusteella kuin verkossa laajalle lukijakunnalle osoitetuissa teksteissä käytettyjen idiomien merkityksiä. Tutkimusta tästä näkökulmasta ei kuitenkaan näytä olevan olemassa, mikä avaakin kiintoisia jatkonäkymiä omalle tutkimuksellemme.

\section{Lähteet}

Ainiala, Terhi - SaArelma, Minna - Sjöblom, Paula 2008: Nimistöntutkimuksen perusteet. Tietolipas 221. Suomalaisen kirjallisuuden seura, Helsinki.

Borin, LARS - Forsberg, MARKUS - ROXENDAL, JoHAN 2012: Korp - the corpus infrastructure of Språkbanken. Saatavilla http://www.korp.csc.fi

CDS = GREen, JonATHON 1998: Cassell's Dictionary of Slang. Cassell, Lontoo.

Clark, Herbert J. - Gerrig, Richard J. 1983: Understanding old words with new meanings. Journal of Verbal Learning and Verbal Behavior 22, 591-608. https://doi.org/10.1016/Soo22-5371(83)90364-X

Croft, William 2001: Radical construction grammar: Syntactic theory in typological perspective. Oxford University Press, Oxford.

DSUE = PARTRIDGE, ERIC 1984: A Dictionary of Slang and Unconventional English: Colloquialisms and Catch Phrases, Fossilised Jokes and Puns, General Nicknames, Vulgarisms and such Americanisms as Have Been Naturalized. 8. painos. Toimittanut Paul Beale. Routledge, Lontoo.

Fillmore, Charles J. - Kay, Paul - O'Connor, Mary Catherine 1988: Regularity and idiomaticity in grammatical constructions: The case of let alone. Language 64 (3), 501-538. https://doi. org/10.2307/414531

Fried, Mirjam - Östman, Jan-Ola 2004: Construction grammar: A thumbnail sketch. MirJam Fried ja Jan-Ola Östman (toim.): Construction grammar in a cross-language perspective. John Benjamins, Amsterdam/Philadelphia, 11-86. https://doi.org/10.1075/cal.2.02fri

Geeraerts, Dirk 1994: Metonymy. R. E. Asher ja J. M. Y. Simpson (toim.): The Encyclopedia of language and linguistics, 2477-8. Pergamon Press, Oxford.

Goldberg, Adele E. 1995: Constructions: A construction grammar approach to argument structure. University of Chicago Press, Chicago.

2006: Constructions at work: The nature of generalization at work. Oxford University Press, Oxford.

Gronow, ANTTI 2012: Bourdieu ja pragmatismi: toimintatavat, habitus ja sosiaalisuuden luonne. Tiede \& edistys 1/2012, 45-61. http://urn.fi/URN:NBN:fi:ELE-1618990

Halliday, M. A. K. - Matthiessen, Christian M. I. M. 2004: An introduction to functional grammar. 3. painos. Arnold, Lontoo.

HAMUnen, Markus 2017: Juosten vai juoksemalla? Infiniittisten ten- ja MALla-rakenteiden semantiikkaa ja murrejakaumaa. Sananjalka 59, 125-153. Saatavilla https://journal.fi/sananjalka/article/ view/66630

2018: MATTA-rakenteen kognitiivista semantiikkaa. Virittäjä 3/2018, 356-386. https://doi. org/10.23982/vir.64471

HeINONEN, TARJA RIITTA 2013: Idiomien leksikaalinen kuvaus kielenkäytön ja vaihtelun näkökulmasta. Unigrafia, Helsinki. http://urn.fi/URN:ISBN:978-952-10-8555-0

Herlin, Ilona - Kotilainen, Lari (toim.) 2012: Verbit ja konstruktiot. Suomi 201. Suomalaisen Kirjallisuuden Seura, Helsinki.

Herlin, IlONA - VisapäÄ, LAURA (toim.) 2005: Elävä kielioppi: suomen infiniittisten rakenteiden dynamiikkaa. SKST 1021. Suomalaisen Kirjallisuuden Seura, Helsinki.

INGO, RUNE 1978: Suomen kielen pluratiivit eli monikkosanat, Numeeris-semanttinen tutkimus I. Väenkokouksia ja teknisiä laitteita tarkoittavat sanat. Åbo Akademi, Åbo.

ISK = Hakulinen, Auli - Vilkuna, Maria - Korhonen, Rittta - Koivisto, Vesa - Heinonen, Tarja 
RiItTA - Alho, IrJa 2004: Iso suomen kielioppi. Suomalaisen Kirjallisuuden Seura, Helsinki.

JäÄSKelÄINEN, ANNI 2013: Todisteena äänen kuva: Suomen kielen imitatiivikonstruktiot. Unigrafia, Helsinki. http://urn.fi/URN:ISBN:978-952-10-8860-5

KARLSSON, GörAN 1960: Numerustutkielmia: kirjoituksia suomen kielen yksikön ja monikon käytöstä. Tietolipas 19. Suomalaisen Kirjallisuuden Seura, Helsinki.

200o: Lehtiväen idiomissa erikoinen monikon käyttötapa. Eeva LäHdemäKI ja YvonNE BeRTILls (toim.): Fennistica fausta in honorem Mauno Koski septuagenarii. Juhlakirja Mauno Kosken 70-vuotispäivän kunniaksi 21.2.200o, 96-104. Åbo Akademi, Åbo.

Kay, Paul - Fillmore, Charles J. 1999: Grammatical constructions and linguistic generalizations: The What's $X$ doing $Y$ ? construction. Language 75 (1), 1-33. https://doi.org/10.1353/lan.1999.0033

KotILAINEN, LARI 2007a: Konstruktioiden dynamiikkaa. Helsingin yliopiston suomen kielen ja kotimaisen kirjallisuuden laitos, Helsinki.

2007b: Kiellon lumo. Kieltoverbitön kieltokonstruktio ja sen kiteytyminen. Suomi 193. Suomalaisen Kirjallisuuden Seura, Helsinki.

LANGaCKeR, Ronald W. 1987: Foundations of cognitive grammar 1: Theoretical prerequisites. Stanford University Press, Stanford.

Leino, JaAkкo 2010: Adele E. Goldberg - väitöskirjalla klassikoksi. Pentti Haddington ja JARi SivONEN (toim.): Kielentutkimuksen modernit klassikot: Kognitiivinen ja funktionaalinen kielitiede, 71-97. Gaudeamus, Helsinki.

Leino, Pentti - Herlin, Ilona -Honkanen, Suvi - Kotilainen, Lari - Leino, JaAkko - VilkKUMAA, MAIJA 2001: Roolit ja rakenteet: Henkilöviitteinen allativi Biblian verbikonstruktioissa. Suomalaisen Kirjallisuuden Seura, Helsinki.

Mikкonen, Pirjo 2003: Erisnimen ja yleisnimen rajankäyntiä. Kielikello 3/2003. Saatavilla https://www.kielikello.fi/-/erisnimen-ja-yleisnimen-rajankayntia [luettu 9.6.2019].

NenONen, MARJA 2002: Idiomit ja leksikko. Suomen kielen lausekeidiomien, syntaktisia, semanttisia ja morfologisia piirteitä. Joensuun yliopiston humanistisia julkaisuja 29. Joensuun yliopisto, Joensuu.

2007a: Prototypical idioms in Finnish. SKY Journal of Linguistics 20, 309-330. Saatavilla https:// www.linguistics.fi/julkaisut/SKY2007/NENONEN.pdf

2007b: Unique but not cranberries: Idiomatic isolates in Finnish. Marja Nenonen ja SinikKa Niemi (toim.): Collocations and idioms 1. Papers from the First Nordic Conference on syntactic freezes, Joensuu, May 19-20, 2006. Studies in Languages 41. Joensuun yliopisto, Joensuu.

Nenonen, MARJA - NiEmi, JUSSI 2004: Mismatches between number and numerosity: perceptual salience and Givon's quantity principles. Nenonen, Marja (toim.): Papers from the 3oth Finnish Conference of Linguistics, Joensuu, May 15-16, 2003. Studies in Languages 39. University of Joensuu, Joensuu.

2010: Mismatches between grammatical number and conceptual numerosity: A number decision experiment on collective nouns, number neutralization, pluralia tanta and idiomatic plurals. Folia Linguistica 43 (2), 127-162. https://doi.org/10.1515/flin.2010.004

Nenonen, Marja - Penttilä, Esa 2014a: Constructional continuity: (Where) does lexicon turn into syntax? The Mental Lexicon 9 (2), 316-337. https://doi.org/10.1075/ml.9.2.07nen

_ 2014b: Eponyymiset idiomit suomen kielessä. XLI Kielitieteen päivät, Turku 8.-10.5. 2014.

Nenonen, Marja - Penttilä, Esa - Niemi, Jussi 2013: Eponymous idioms in two languages. The Fourth Conference of the Scandinavian Association for Language and Cognition (SALC IV), Joensuu, June 12-14, 2013.

Nicolas, Tim 1995: Semantics of idiom modification. Martin Everaert, Erik-Jan van der Linden, Andre Schenk ja Rob Schreuder (toim.): Idioms: Structural and psychological perspectives, 233-252. Lawrence Erlbaum Associates, Hillsdale.

Niemi, Jussi - Nenonen, Marja - Penttilë, Esa 1998: Number as a marker of idiomaticity. Timo Haukioja (toim.): Proceedings of the XVIth Scandinavian Conference of Linguistics, Turku/Åbo, November 14-16, 1996. Åbo Akademis Tryckeri, Åbo.

Paunonen, Heikki - Paunonen, Marjatta 2000: Tsennaaks Stadii, bonjaaks slangii. Stadin slangin 
suursanakirja. WSOY, Helsinki.

Penttilä, Aarni 1957: Suomen kielioppi. WSOY, Porvoo.

PentTilä, Esa 2006: It takes an age to do a chomsky: Idiomaticity and verb phrase constructions in English. Väitöskirja. Joensuun yliopisto, Englannin kieli.

2010: A prototype-based taxonomy of idiomatic expressions. ElżBIeta Tabakowska, Michą CHOIŃsKi ja ŁUKASz WirAszKa (toim.): Cognitive linguistics in action: From theory to application and back, 145-162. Mouton de Gruyter, Berlin/New York.

Rapp, David N. - Gerrig, Richard J. 1999: Eponymous verb phrases and ambiguity resolution. Memory \& Cognition 27 (4), 612-618. https://doi.org/10.3758/BF03211555

Ritchie, L. David 2017: Metaphor and story-telling. Elena Semino ja Zsófia Demjén (toim.): The Routledge handbook of metaphor and language, 337-352. Routledge, New York.

Sјöвlom, PAUla 2006: Toiminimen toimenkuva: suomalaisen yritysnimistön rakenne ja funktiot. Suomalaisen Kirjallisuuden Seura, Helsinki.

Yli-VAKKURI, VAlMa 1986: Suomen kieliopillisten muotojen toissijainen käyttö. Turun yliopisto, Turku.

\section{Marja Nenonen and Esa Penttilä: Eponymous idioms in Finnish - verb phrase constructions referring to presidents as an example case}

This article discusses the Finnish eponymous verb phrase construction tehd $\ddot{a}+\mathrm{N}_{\text {prop }}-\mathrm{PL}$, instantiated by phrases such as tehdä Kekkoset 'to pull/do a Kekkonen' or tehdä haloset 'to pull/do a Halonen'. In this construction, the pluralised proper noun, which functions as the object of the verb tehdä 'to do', is used as an appellative and refers to a characteristic, action or activity linked to the name rather than specifies the actual name bearer. As a consequence, the meaning of the idiomatic construction vastly varies, depending the context. This article scrutinises the situational meaning of the eponymous construction by analysing corpus data, concentrating on expressions in which the eponym is the name of a Finnish president. This criterion helped limit the material to a manageable size, and since the presidents are wellknown figures, the meanings related to them are either commonly understandable or fairly easily traceable. As a result of semantic analysis, the situational meanings of the construction in the data could be divided into three groups that have to do with the 1) politics, 2) private life or 3 ) habitus of the president in the phrase. All in all, the idiomatic eponymous verb phrase construction provides a very efficient way of communicating information in a very condensed manner, by adjusting its final situational meaning to the surrounding context.

\author{
Marja Nenonen \\ marja.nenonen@uef.fi \\ Suomen kieli \\ Itä-Suomen yliopisto \\ PL 111, 80101 Joensuu
}

Esa Penttilä esa.penttila@uef.fi

Käännöstiede

Itä-Suomen yliopisto

PL 111, 80101 Joensuu 
Lite 1.

Aineiston eponyymisten konstruktioiden kontekstista päätellyt tilanteiset merkitykset

$\mathrm{N}=299$

123 erilaista tilanteista merkitystä

poliittinen teko $(\mathrm{N}=133,61$ erilaista tilanteista merkitystä)

pienentää omaa palkkaansa (MA 4, TH 1, SN 17)

ryhtyä syntipukiksi (RR 9)

käyttää ulkopolitiikkaa hyväksi sisäpolitiikassa (UKK 6, SN 1)

lopettaa lakko uhkailemalla (UKK 5, SN 1)

olla rähmällään (UKK 6)

käyttää presidentin nimitysoikeutta (TH 3 ,

UKK 1, MK 1)

leikkiä tietämätöntä (SN 5)

mennä maan alle (SN 4)

palauttaa presidentin valtaoikeudet (UKK 3)

pestä kätensä (UKK 3)

pitää kokoomus ikuisessa oppositiossa (UKK

aiheuttaa diplomaattinen kriisi (TH 2)

haastaa istuva presidentti (CGM 2)

kaataa hallitus (UKK 2)

saunottaa vieraat (UKK 2)

sietää oppositiota (UKK 2)

vähentää presidentin valtaoikeuksia (MK 2)

antaa katteettomia lupauksia (MK)

ehdottaa työttömien aktivointia (SN)

estää jalkaväkimiinat (TH)

hoitaa politiikan rinnalla kauppasuhteita

(UKK)

ilmaista olevansa isänmaallinen (SN)

ilmoittaa itsensä ISISin viholliseksi (SN)

järjestää tiestö kuntoon (UKK)

jättää joku kutsumatta (MA)

jättää laki vahvistamatta (UKK)

jättää tilaisuus käyttämättä (MK)

kutsua joku muodostamaan hallitus (UKK)

kutsua paluumuuttajia (MK)

käyttää juoksupoikaa (UKK)

käyttää bulvaania (SN)

laistaa vastuuta taloudellisesta päätöksestä

(MK)

liittyä euroon (SN)

lähteä ulkomaille tuomiota pakoon (CGM)

muodostaa sinipunahallitus (MK)

myöntää virheensä (MK)

nostaa eläkeikää (UKK)

nostaa kätensä ilmaan (JKP)

nostaa minimipalkkoja (UKK) olla ottamatta valtionvelkaa (RR)

olla piittaamatta köyhistä $(\mathrm{TH})$

olla varovainen lausunnoissaan (SN)

onnistua valtionvarainministerinä (MK)

painostaa mediaa $(\mathrm{SN})$

pettää lupauksensa (TH)

pysyä vaiti väittelyssä (SN)

pyytää anteeksi (MK)

pääministeri nousee presidentin tahtoa

vastaan $(\mathrm{MK})$

rukoilla Suomen puolesta (KK)

selitellä (SN)

suosia ruotsinkielisiä (MA)

tehdä yya-sopimus (JKP)

tilata noottikriisi (UKK)

toimittaa epätoivottu poliitikko ulkomaille

(SN)

tukehduttaa keskustelu (SN)

uhata erolla, jos näkemyksiä ei hyväksytä (CGM)

vaatia vakoilijan palautusta $(\mathrm{SN})$

viivytellä kommentoinnissa (TH)

vinoilla kansalaisille $(\mathrm{TH})$

vähätellä kustannuksia (SN)

vaalit $(\mathrm{N}=70,21$ erilaista tilanteista

merkitystä)

tulla valituksi aina uudestaan (UKK 21)

nousta valtaan mustana hevosena (MA 8,

TH1, UKK 1)

menestyä naisehdokkaana (TH 5)

tulla valituksi ensimmäisellä kierroksella

(UKK 1, SN 3, JKP 1)

tulla valituksi toisella yrittämällä (SN 4)

jäädä pois päivänpolitiikasta (MK 1, SN 1 , JKP 1)

vetäytyä vaalista (SN 2, RR 1)

kerätä vaalirahaa arpajaisilla (TH 2)

kieltäytyä ehdokkuudesta (SN 2)

toimia ääniharavana (SN 2)

yhden kauden presidentti (MA 2)

jättää tekemättä vaalirahaselvitys (SN)

kasvattaa suosiotaan puoluetaustansa vastaisilla lausunnoilla (MK)

käydä raskasta vaalikampanjaa (TH)

käyttää köyhää lapsuutta vaalikampanjassa (UKK)

mennä naimisiin vaalien alla $(\mathrm{SN})$

toivottaa vastustajalle onnea (UKK)

valita sosiaalidemokraatti presidentiksi (MA) 
viedä toiselta kannatusta ( $\mathrm{SN}$ )

välttää kiusallisia aiheita (SN)

äänestää omantunnon mukaan (SN)

habitus $(\mathrm{N}=66,25$ erilaista tilanteista merkitystä)

ottaa itseään huomattavasti nuorempi puoliso (SN 23)

siviiliura rauhanvälittäjänä (MA 7)

kaljuus (UKK 5)

kävelytyyli (MA 3)

saada muistikatkoksia (TH 1, UKK 2)

asua puolison kanssa eri asunnoissa (TH 2)

olla kulissiavioliitossa (TH 2)

opiskella iltakoulussa (MK 2)

pukeutua väärällä tavalla (TH 2)

jahkailla (MK)

kulkea ilman turvamiehiä (TH)

olla ateisti (MK)

olla imartelulle altis (UKK)

olla mielistelemättä ketään (SN)

olla provosoitumatta (MK)

opiskella nuorena ahkerasti (SN)

osata venäjän kieltä (CGM)

pitää vahvoja silmälaseja (UKK)

rahanahneus (MA)

rullaluistella $(\mathrm{SN})$

shoppailla marketissa (TH)

tehdä koko työuransa politiikassa $(\mathrm{TH})$

yletä armeijassa suhteilla (SN)

ylimielisyys (SN) yksittäinen tapaus $(\mathrm{N}=30,14$ erilaista tilanteista merkitystä)

kaatua (MA 6, UKK 5)

kiivetä palmuun (UKK 7)

antaa yksinoikeus haastatteluun $(\mathrm{TH})$

harrastaa kaukomatkailua (CGM)

hermostua toimittajiin $(\mathrm{TH})$

hypätä yhdellä loikalla ylimmälle rappuselle (UKK)

karata sodasta (CGM)

katsoa viisituntinen elokuva yhdellä istumalla (UKK)

laittaa kala valmiiksi vieraan koukkuun (UKK)

mennä salaa naimisiin (SN)

paljastaa pseudonyyminsä (UKK)

tarjota maahanmuuttajalle kahvit (MA)

voittaa Nobelin palkinto (MA)

vältellä mediaa (UKK)

\section{Lyhenteet}

MA = Martti Ahtisaari

$\mathrm{TH}=$ Tarja Halonen

KK $=$ Kyösti Kallio

UKK = Urho Kaleva Kekkonen

MK = Mauno Koivisto

CGM = Carl Gustaf Mannerheim

$\mathrm{SN}=$ Sauli Niinistö

JKP = Juho Kusti Paasikivi

$\mathrm{RR}=$ Risto Ryti

\section{Liite 2.}

Eponyymikonstruktioiden tilanteisten merkitysten jakauma

$\begin{array}{llllll}\text { presidentti } & \begin{array}{l}\text { poliittinen } \\ \text { teko }\end{array} & \begin{array}{l}\text { vaalit } \\ \text { habitus }\end{array} & \begin{array}{l}\text { yksittäinen } \\ \text { tapaus }\end{array} & \text { Yht. } \\ \text { Niinistö } & 43 & 19 & 29 & 1 & 92 \\ \text { Halonen } & 11 & 10 & 10 & 2 & 33 \\ \text { Ahtisaari } & 6 & 11 & 12 & 8 & 37 \\ \text { Koivisto } & 18 & 2 & 5 & & 25 \\ \text { Kekkonen } & 38 & 25 & 9 & 17 & 89 \\ \text { Paasikivi } & 4 & 2 & & & 6 \\ \text { Mannerheim } & 2 & & 1 & 2 & 5 \\ \text { Ryti } & 10 & 1 & & & 11 \\ \text { Kallio } & 1 & & & & \mathbf{2 9 9} \\ \text { Yht. } & \mathbf{1 3 3} & \mathbf{7 0} & \mathbf{6 6} & \mathbf{3 0} & \end{array}$

